\title{
Bacterial Profile and Their Antibiogram Isolated from Cell Phones
}

\author{
Bikrant Gumanju ${ }^{1}$, Roshna Shrestha ${ }^{1}$, Poonam Lakhemaru ${ }^{1}$, Rakysa Upadhyaya ${ }^{1}$, Sushila Shrestha ${ }^{1}$, \\ Dinesh Dhakal ${ }^{1}$, Upendra Thapa Shrestha ${ }^{2 *}$ \\ ${ }^{1}$ Department of Microbiology, Sainik Awasiya Mahavidhyalaya, Sallaghari, Bhaktapur \\ ${ }^{2}$ Central Department of Microbiology, Tribhuvan University, Kirtipur, Kathamandu
}

*Corresponding author: Upendra Thapa Shrestha, Assistant Professor, Central Department of Microbiology, Tribhuvan University, Kirtipur, Kathmandu, E-mail: upendrats@gmail.com

\section{ABSTRACT}

Objectives: The present study aimed to identify bacteria profile of cell phones used by different people from different profession of Bhaktapur and to access their antimicrobial resistance.

Methods: Forty-nine mobile swab samples were collected from 7 different profession category (7 samples each from student, butcher, cook, pani puri vendor, health workers, and dairy employee). Samples were cultured and processed by standard Microbiological procedures. All the isolates were further subjected to antibiotic susceptibility testing using modified Kirby Bauer disc diffusion method as describe in CLSI guidelines. The rate of multiple drug resistant (MDR) bacteria was also determined.

Results: Out of 49 sample, Bacillus spp (20.4\%) was the most predominant isolate, followed by Staphylococcus aureus (10.6\%) and Pseudomonas spp (10.6\%). Higher variety of bacterial isolates was found in the cell phones swabs from butcher followed by cook, farmer and pani puri vendor group. The data from the questionnaire showed that handkerchief or tissue paper were mostly used by respondents to clean their mobile. All Gram-positive and Gram-negative isolates were resistance to Cefoxitin (100\%) except Micrococcus spp and Neisseria spp. Gram positive (18.2\%) and Gram-negative $(36.9 \%)$ isolates were identified as MDR. All S. aureus and coagulase negative staphylococci were methicillin resistant

Conclusion: The cell phones of people from different profession were found to possess many different bacterial pathogens including multi drug resistant strains which could be the possible pathogens for food borne infections and opportunistic infections.

Key words: Cell phones, Antimicrobial susceptibility test, MDR, Standard microbiological procedure

\section{INTRODUCTION}

Microorganisms live almost everywhere on Earth from the liquid water, including hot springs and the ocean floor, rocks deep inside Earth's crust. A huge load of microorganisms is also present in the daily life stuffs like electronic devices, ornaments, study materials etc. Electronic devices include mobile phone, television, laptop etc (Madigan and Martinko 2006). Cell phones might act as fomites as they are carried to the places such as toilets, hospitals and kitchens where they are

Date of Submission: October 3, 2019

Published Online: December, 2019 loaded with microorganisms (Bhoonderowa et al. 2014).

The recent evaluation of microbial contamination in mobile phone of dental and engineering schools in Iran reported the higher percentage of mobile phones were contaminated and mainly by S. aureus (Fard et al. 2017). Similarly, recent bacterial isolates from mobile phone surface of students of University of Kufa, Iraq found Bacillus spp, as the predominant ones followed by $S$. aureus and S. epidermis (Harmoosh et al. 2017). Likewise,

Date of Acceptance: November 27, 2019

DOI: https:/ / doi.org/10.3126/tujm.v6i0.26591 
the research at University of Gondar, Ethiopia, showed higher number of E. coli, E. aerogenes, Streptococcus spp and $S$. aureus isolates in the mobile phones of students and employee (Verma et al. 2015).

In an urban teaching hospital in Durban, South Africa, the study had showed that Gram-positive microorganisms were more frequently cultured from Caregivers phones and predominantly contaminated with Staphylococcus spp. (Bobat et al. 2017). It was found that mobile phones are ten times dirtier than toilet seats. Due to carelessness about the pathogenic organisms, people don't give a second thought to use their cell phone everywhere from morning commute to the dinner table, to doctor office to respective workplace (Abrams 2017). In the study of hospital survey in Nepal, Health care workers used their cell phone in the hospital and many of them never cleaned their cell phone. Among them, 20\% didn't even practice hand washing before or after attending patients and used their cell phones immediately (Chawla et al. 2009). In 2017, Adhikari et al. reported the presence of $S$. aureus and Methicillin resistant $S$. aureus associated with mobile phones (Adhikari et al. 2017). The research on mobile phone as a possible vector of bacterial transmission in hospital setting was conducted in Dhulikhel hospital, Nepal and revealed that bacterial growth was positive for pathogenic organisms in 89 out of 124 mobile phones (Karkae et al. 2017).

Use of mobile phones in sensitive areas is the subject of controversy as there are no guidelines for disinfection of mobile phones that meet standards and some people are unaware of the fact that mobile phones act as the fomite for transmission of pathogens. So, the focus should be on how to use mobile phones sensibly, getting their benefits and minimizing their risks (Ulger et al.2009). Hence, the present study was undertaken to examine the mobile phones of respective profession people for presence of bacteria, as mobile phones transmitted infections possess a constant threat to lives of people living around. This study was also aimed to find the correlation between the organisms and if any behavioral/ professional traits determines the types of organisms to be found in the phones. Moreover, we assessed the antibacterial resistance pattern of bacteria isolated from these phones along with MDR load.

\section{MATERIALS AND METHODS}

\section{Sample collection}

Forty-nine cell phone swabs were collected people of seven different profession (farmer, cook, butcher, student, pani puri installer, dairy employee and health workers) in Bhaktapur. Sterile swab moistened with normal saline were used for the sample collection.

\section{Bacterial identification}

The sample collected were immediately transported to laboratory of Sainik Awasiya Mahavidhyalaya and processed to identify the bacterial isolates by using standard microbiology procedures including Gram staining and biochemical tests.

\section{Antibiotic susceptibility testing}

Antibiotic sensitivity testing was performed for those isolates using the Kirby-Bauer disc diffusion method on Mueller-Hinton agar according to CLSI guidelines (CLSI 2012). Antibiotics; cefoxitin, vancomycin, chloramphenicol, ampicillin, norfloxacin, azithromycin, tetracycline and nalidixic Acid were used for Gram-positive isolates while cefoxitin, vancomycin, chloramphenicol, ampicillin, norfloxacin, erythromycin and polymyxin $b$ were tested against Gram-negative isolates. Those which were resistant to 3 or more different classes of antibiotics were categorized as multi drug resistant strains.

\section{RESULTS}

\section{Bacterial contamination of cell phones}

Out of forty-nine samples from cell phones, 48(98\%) showed bacterial growth while only one sample $(2 \%)$ from health worker's cell phone wasn't contaminated. A total of 146 bacterial isolates were isolated in which $79(54.1 \%)$ was Gram positive and $67(45.9 \%)$ Gram negative.

The cell phone of health workers was the least contaminated with bacteria $(7.7 \%)$ with high Grampositive isolates (7\%) whereas those from butcher group had higher bacterial isolates $(19.8 \%)$ followed by cook $(18.4 \%)$, farmer $(16.9 \%)$, pani puri vendor $(16.2 \%)$ etc. 


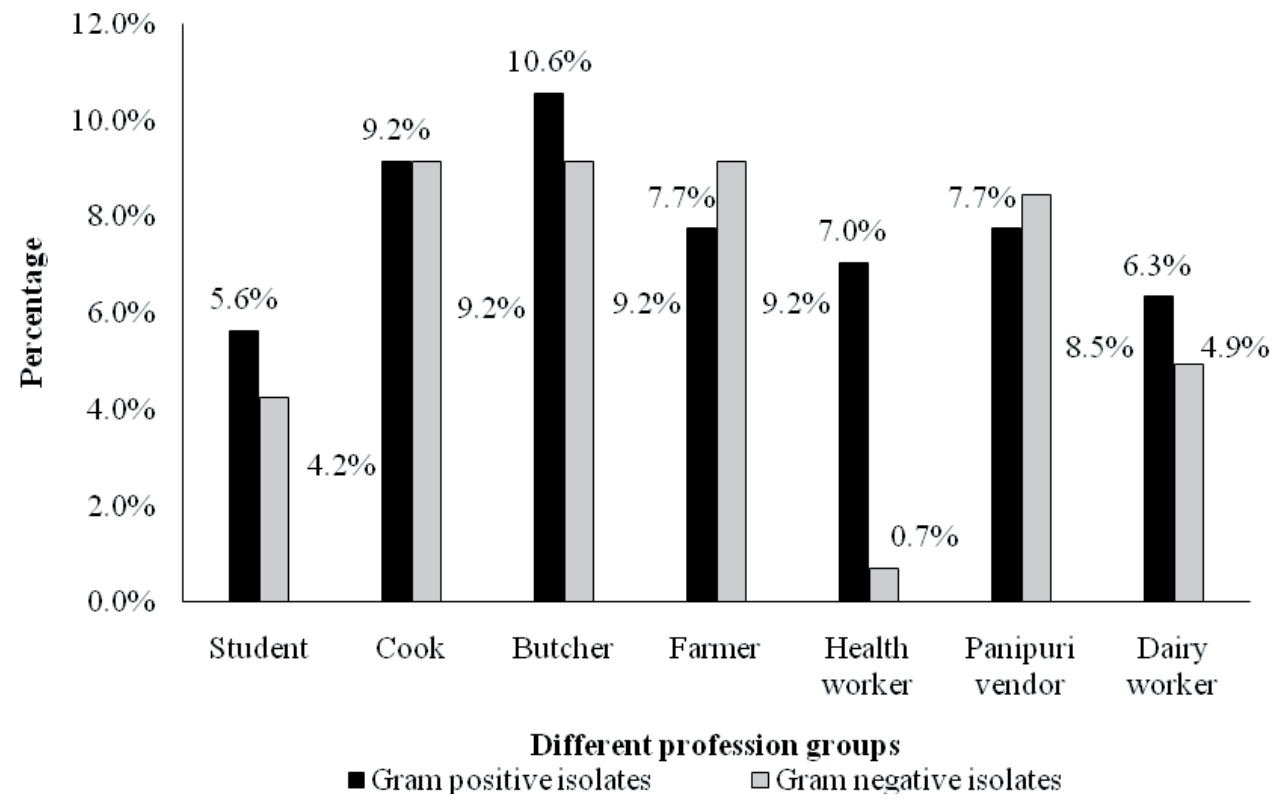

Figure 1: Gram positive and Gram-negative isolates on different groups

\section{Bacterial profile}

Among the different bacterial isolates from cell phones, Bacillus spp (20\%) was the most predominate Grampositive isolate followed by S. aureus (11.0\%). Similarly, among Gram-negative isolates, Pseudomonas spp $(10.3 \%)$ was mostly commonly isolated followed by Proteus spp (9.7\%) (Table 1).

Table 1: Frequency of bacterial isolates from cell phones

\begin{tabular}{|c|c|c|c|c|c|c|c|c|}
\hline \multirow[b]{2}{*}{ Bacterial isolates } & \multicolumn{7}{|c|}{ Percent (\%) of isolates from cell phone of professions } & \multirow[b]{2}{*}{ Total } \\
\hline & Student & Cook & Butcher & Farmer & $\begin{array}{l}\text { Health } \\
\text { worker }\end{array}$ & $\begin{array}{l}\text { Pani puri } \\
\text { vendor }\end{array}$ & $\begin{array}{c}\text { Dairy } \\
\text { worker }\end{array}$ & \\
\hline Bacillus spp & 3.4 & 4.1 & 2.8 & 2.8 & 1.4 & 3.4 & 2.1 & 20.0 \\
\hline S. aureus & 0.7 & 0.7 & 3.4 & 1.4 & 1.4 & 1.4 & 2.1 & 11.0 \\
\hline Pseudomonas spp & 0 & 2.1 & 2.1 & 3.4 & 0 & 0.7 & 2.1 & 10.3 \\
\hline Proteus spp & 0 & 3.4 & 1.4 & 2.1 & 0 & 2.1 & 0.7 & 9.7 \\
\hline Corynebacterium spp & 0 & 0.7 & 0.7 & 3.4 & 2.8 & 1.4 & 0.7 & 9.7 \\
\hline Citrobacter spp & 2.8 & 0.7 & 1.4 & 1.4 & 0 & 2.1 & 0 & 8.3 \\
\hline Klebsiella spp & 0.7 & 1.4 & 2.1 & 1.4 & 0 & 1.4 & 0.7 & 7.6 \\
\hline S. epidermis & 0 & 1.4 & 2.1 & 0 & 0 & 0 & 0.7 & 4.1 \\
\hline Micrococcus spp & 0.7 & 2.1 & 0 & 0 & 0 & 0.7 & 0 & 3.4 \\
\hline E. coli & 0 & 0.7 & 0 & 0 & 0.7 & 1.4 & 0 & 2.8 \\
\hline Enterobacter spp & 0.7 & 0 & 0.7 & 0.7 & 0 & 0.7 & 0 & 2.8 \\
\hline Streptococcus spp & 0 & 0 & 2.1 & 0 & 0 & 0 & 0 & 2.1 \\
\hline Providencia spp & 0 & 0 & 0.7 & 0 & 0 & 0 & 0 & 0.7 \\
\hline Shigella spp & 0 & 0 & 0 & 0 & 0 & 0 & 0.7 & 0.7 \\
\hline Salmonella spp & 0 & 0.7 & 0 & 0 & 0 & 0 & 0 & 0.7 \\
\hline Unidentified & 0.7 & 0 & 1.4 & 0.7 & 1.4 & 0.7 & 1.4 & 6.2 \\
\hline Total bacterial isolates & 9.7 & 17.9 & 20.7 & 17.2 & 7.6 & 15.9 & 11.0 & 100 \\
\hline
\end{tabular}


Antibiotic susceptibility pattern of Gram-positive isolates

Almost all Gram-positive isolates were resistance to cefoxitin (100\%) except Micrococcus spp. All the Gram- positive isolates were sensitive to norfloxacin followed by chloramphenicol. $56 \%$ of Gram-positive isolates were found to be tetracycline resistant (Table 2).

Table 2: Antibiotic susceptibility pattern of Gram-positive isolates

\begin{tabular}{|c|c|c|c|c|c|c|c|c|}
\hline \multirow{2}{*}{$\begin{array}{l}\text { Antibiotic used / } \\
\text { Gram positive isolates }\end{array}$} & \multicolumn{8}{|c|}{ No of Gram-positive isolates resistant to (\%) } \\
\hline & $\mathrm{CX}$ & $\mathrm{Va}$ & C & AMP & Nx & AZMI & TET & NV \\
\hline Bacillus spp ( $\mathrm{n}=29)$ & $\begin{array}{c}29 \\
(100)\end{array}$ & $\begin{array}{c}29 \\
(17.2)\end{array}$ & 0 & 0 & 0 & 0 & $\begin{array}{c}2 \\
(6.9)\end{array}$ & 0 \\
\hline S. aureus $(n=16)$ & $\begin{array}{c}16 \\
(100)\end{array}$ & $\begin{array}{c}4 \\
(25)\end{array}$ & 0 & 0 & 0 & $\begin{array}{c}16 \\
(100)\end{array}$ & $\begin{array}{c}13 \\
(81.3)\end{array}$ & $\begin{array}{c}16 \\
(100)\end{array}$ \\
\hline Corynebacterium spp $(\mathrm{n}=14)$ & $\begin{array}{c}14 \\
(100)\end{array}$ & $\begin{array}{c}3 \\
(21.4)\end{array}$ & 0 & $\begin{array}{c}6 \\
(42.9)\end{array}$ & 0 & 0 & $\begin{array}{c}14 \\
(100)\end{array}$ & 0 \\
\hline S. epidermis $(n=6)$ & $\begin{array}{c}6 \\
(100)\end{array}$ & $\begin{array}{c}3 \\
(50)\end{array}$ & 0 & 0 & 0 & $\begin{array}{c}6 \\
(100)\end{array}$ & $\begin{array}{c}1 \\
(16.7)\end{array}$ & $\begin{array}{c}6 \\
(100)\end{array}$ \\
\hline Streptococcus spp $(\mathrm{n}=3)$ & $\begin{array}{c}3 \\
(100)\end{array}$ & 0 & 0 & $\begin{array}{c}2 \\
(66.7)\end{array}$ & 0 & 0 & $\begin{array}{c}3 \\
(100)\end{array}$ & 0 \\
\hline Lactobacillus spp ( $\mathrm{n}=7$ ) & $\begin{array}{c}7 \\
(100)\end{array}$ & 0 & $\begin{array}{c}3 \\
(42.9)\end{array}$ & 0 & 0 & $\begin{array}{c}2 \\
(28.6)\end{array}$ & $\begin{array}{c}7 \\
(100)\end{array}$ & 0 \\
\hline Micrococcus spp $(\mathrm{n}=5)$ & 0 & $\begin{array}{c}2 \\
(40)\end{array}$ & 0 & $\begin{array}{c}4 \\
(80)\end{array}$ & 0 & $\begin{array}{c}1 \\
(20)\end{array}$ & $\begin{array}{c}5 \\
(100)\end{array}$ & 0 \\
\hline
\end{tabular}

Note: Cx: Cefoxitin, Va: Vancomycin, C: Chloramphenicol, Amp: Ampicillin, Nx: Norfloxacin, Azmi: Azithromycin, Tet: Tetracycline, Nv: Nalidixic Acid.

Antibiotic susceptibility pattern of Gram-negative isolates

Major Gram-negative isolates were resistance to cefoxitin (100\%) except Neisseria spp. Bacteria were resistant to polymyxin $\mathrm{B}$ followed by vancomycin, erythromycin and ampicillin (Table 3).

Table 3: Antibiotic susceptibility pattern of Gram-negative isolates

\begin{tabular}{|c|c|c|c|c|c|c|c|}
\hline \multirow{2}{*}{$\begin{array}{l}\text { Antibiotic used / } \\
\text { Gram negative isolates }\end{array}$} & \multicolumn{7}{|c|}{ No. of resistant isolates/Total no. of Gram-negative isolates } \\
\hline & PB & $E$ & $\mathrm{C}$ & $\mathrm{Nx}$ & $\mathrm{Va}$ & AMP & $C x$ \\
\hline Klebsiella spp $(\mathrm{n}=11)$ & $\begin{array}{c}11 \\
(100)\end{array}$ & $11(100)$ & 0 & $1(9.1)$ & $1(9.1)$ & $3(27.3)$ & $11(100)$ \\
\hline Citrobacter spp $(n=12)$ & 0 & $10(83.3)$ & $4(33.3)$ & 0 & 0 & $3(25.0)$ & $12(100)$ \\
\hline Enterobacter spp $(n=4)$ & $2(50)$ & $4(100)$ & 0 & 0 & $2(50)$ & $3(75)$ & $4(100)$ \\
\hline Pseudomonas spp $(n=15)$ & $\begin{array}{c}13 \\
(86.7)\end{array}$ & $10(66.7)$ & $13(86.7)$ & 0 & $10(66.7)$ & $11(73.3)$ & $15(100)$ \\
\hline Proteus spp $(n=14)$ & $(100)$ & 0 & $10(71.4)$ & $1(7.1)$ & $8(57.1)$ & $6(42.9)$ & $14(100)$ \\
\hline Salmonella spp $(\mathrm{n}=1)$ & $1(100)$ & $1(100)$ & 0 & 0 & $1(100)$ & $1(100)$ & $1(100)$ \\
\hline E. coli $(\mathrm{n}=4)$ & $4(100)$ & $3(75)$ & 0 & 0 & $4(100)$ & 0 & $4(100)$ \\
\hline Providencia spp $(\mathrm{n}=1)$ & $1(100)$ & $1(100)$ & $1(100)$ & 0 & $1(100)$ & $1(100)$ & $1(100)$ \\
\hline Neisseria spp $(\mathrm{n}=2)$ & $\begin{array}{l}2 / 2 \\
(100)\end{array}$ & $\begin{array}{l}2 / 2 \\
(100)\end{array}$ & 0 & 0 & $2(100)$ & 0 & $1(50)$ \\
\hline Shigella spp $(\mathrm{n}=1)$ & $1(100)$ & $1(100)$ & 0 & 0 & $1(100)$ & $1(100)$ & $1(100)$ \\
\hline
\end{tabular}

Note: Cx: Cefoxitin, Va: Vancomycin, C: Chloramphenicol, Amp: Ampicillin, Nx: Norfloxacin, E: Erythromycin, PB: Polymyxin B.

\section{Multi drug resistant strains}

Out of 145 isolates, 50 isolates (34.5\%) were observed to be MDR isolates. Among them, twenty-six isolates were Gram positive and twenty-four were Gram negative (Figure 2). 


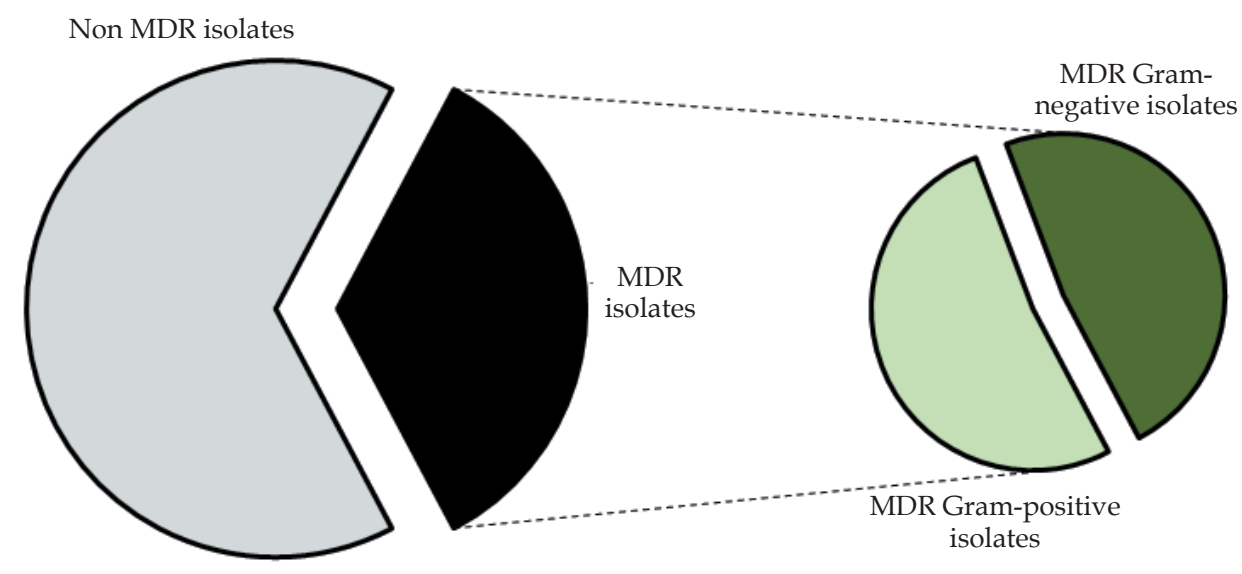

Figure 2: Multidrug resistant isolates

\section{DISCUSSION}

In present study, $98 \%$ of sample mobile phones showed bacterial contamination. Rate of contamination of mobile phones in present study seemed to be higher than previous studies. Kotris et al. (2016) reported $84 \%$ of mobile phone of students were contaminated. According to Adhikari et al. (2018), 56\% of mobile phones of students and staff contained bacterial agents. Mobile phones of $98 \%$ students of dental school were contaminated by bacterial agents. The higher percentage of bacterial contamination in mobile phones of health worker and students might be due to over use of mobile phones at work place, washroom and even at dining with lack of hand washing practice.

According to Karkee et al. (2017), Gram positive bacteria (79.81\%) dominant over Gram negative (20.19\%-) in the survey done at Dhulikhel hospital. Ramesh et al. (2008) reported that $46 \%$ of mobile phones of medical staff and students were positive culture with $15 \%$ belonging to Gram-negative pathogens and $85 \%$ were Gram positive. According to international journal of infection control, $56.67 \%$ of bacterial isolates were Gram positive whereas $43.33 \%$ were Gram negative isolates. Akinyemi et al. (2009) also mentioned huge percentage of Grampositive isolates i.e. $83.87 \%$ and low Gram-negative isolates $(16.13 \%)$. This study showed similar results as compared to other results. The higher rate of Gram positive might be originated from skin normal flora.

Bacillus spp was found to be the most predominant one $(20.4 \%)$ of total microbial population from the 49 swabbed samples followed by S. aureus $(11.0 \%)$. This might be due to its presence everywhere in nature and its spore forming characteristics. Bacillus spp with a $100 \%$ frequency of occurrence has been identified as an important organism in food spoilage by Dave and Shende (2015) in Chhattisgarh region, India. The research carried out in University of Peradeniya, Sri Lanka of veterinary undergraduate students by Viveka (2017) reported that dominant organisms were S. epidermis $(87.5 \%)$, Bacillus spp $(60 \%)$, Pseudomonas spp $(50 \%)$, S. aureus $(22.5 \%)$ etc. Results of this investigation show the potential of cell phones to participate as fomites and a vehicle of different types of microorganisms.

All the Gram-positive isolates were observed to be resistant to cefoxitin (100\%) except Micrococcus spp but most of all isolates were sensitive to norfloxacin and chloramphenicol. Bacillus spp were resistant to vancomycin (17.2\%) and tetracycline (6.9\%). These findings were similar to resistant pattern of bacterial isolates in sachet water sold in the streets of Cape Coast (Tagoe et al. 2011). The survey from Dhulikhel hospital reported that most of the Gram-positive cocci were sensitive to vancomycin and ciprofloxacin. S. epidermis and Micrococcus spp were reported to be most sensitive to vancomycin $(81.36 \%, 75 \%)$. S. aureus were not reported as resistant to vancomycin and erythromycin was $80 \%$. In the survey performed in Bangladesh, $27.3 \%$ of S. aureus were resistant to azithromycin, $36.4 \%$ to tetracycline and $31.8 \%$ to chloramphenicol. Also 37.5\% and $68.8 \%$ of S. epidermis were resistant with tetracycline and ampicillin respectively Debnath et al. (2018). 
Most of all the Gram-negative isolates were resistant to polymyxin b, erythromycin, vancomycin, ampicillin and cefoxitin. Klebsiella spp were identified as polymyxin b (100\%), erythromycin $(100 \%)$ and cefoxitin $(100 \%)$ resistant. In study conducted by Akinyemi et al. $80.7 \%$ of total bacteria were sensitive to ciprofloxacin. Debnath et al. (2018) reported $45.5 \%$ of Pseudomonas spp were resistant to Tetracycline and 50\% and $35.7 \%$ of E. coli were resistant to chloramphenicol and tetracycline respectively. Salmonella spp were resistant to chloramphenicol (50\%) and tetracycline (16.7\%).

In this study, after Bacillus spp; Staphylococcus spp were found to be high (i.e. 13.9\%) which were all resistant to norfloxacin, cefoxitin and azithromycin. As all the Staphylococcus species were resistant to cefoxitin, it could be assumed to be MRSA. This assumption was supported by Jain et al. (2008) which stated that use of disc diffusion test for both oxacillin and cefoxitin could help in more accurate prediction of methicillin resistant. MRSA is of particular importance in the medical community, as it has evolved resistance to $\beta$-lactam antibiotics (Jonathan et al. 2010). 59\% of Methicillin resistant S. aureus and 37.7\% of Methicillin resistant CoNS were also reported by Worku et al. (2018) in Mizan- Tepi university teaching hospital, Southwest Ethiopia.

From the antibiotic sensitivity testing, it was observed that most of the isolates obtained from cell phones of different profession groups were showing growth of multi drug sensitive organisms. A total of $18.2 \%$ of Gram positive MDR isolates were secured among 77 of Gram-positive isolates whereas $36.9 \%$ of Gram negative MDR isolates were secured among 65 of total Gram-negative isolates. Multidrug resistant S. aureus, Klebsiella, Proteus spp, Pseudomonas spp and E. coli were reported by Worku et al. (2018) with a percentage of $21 \%, 53.8 \%, 44.4 \%, 30 \%$ and $7.1 \%$ respectively. Loyola et al. (2018) reported that $2.9 \%$ of Pseudomonas spp and $46.7 \%$ of $S$. aureus were reported as MDR from the health care workers cell phones at Peruvian hospital.

Many of the previous studies revealed that people do not consider mobile phones to be contaminated items and rarely disinfect their phones (Ramesh et al. 2008). Hand washing is the most effective method for the prevention of bacterial transmission. Although there are strict rules on hand hygiene in hospitals, it is not possible to provide de-contamination, disinfection or sterilization of each device used personally. Periodic disinfection of instruments and surfaces that often come into contact with the hands, such as computer keyboards and mouse, was recommended by the Centers for Disease Control and Prevention (CDC)'s guidelines (Boyce and Pittet 2002).

\section{CONCLUSION}

The Cell phones of people from different profession were found to possess many different bacterial pathogens including multi drug resistant strains which could be the possible pathogens for food borne infections and opportunistic infections. Based on this study, it seems to be essential to aware people about the possible risk of transferring MDR while using mobile phone at workplace.

\section{ACKNOWLEDGEMENTS}

We would like to thank all staff members of Department of Microbiology, Sainik Awasiya Mahavidhyalaya, Sallaghari, Bhaktapur and all the cell phone users who participated in this study.

\section{CONFLICT OF INTEREST}

The authors declare no conflict of interest.

\section{REFERENCES}

Abrams A (2017). Time health: your cell phone is 10 times dirtier than a toilet seat. Here' what to do about it. Retrieved from http://time. com/4908654/cell-phonebacteria/

Adhikari S, Khadka S, Sapkota S and Shrestha P (2018). Methicillin Resistant Staphylococcus aureus associated with mobile phones. SOJ Microbiol Infect Dis 6: 1-6.

Akinyemi KO, Atapu AD, Adetona OO and Coker AO (2009). The potential role of mobile phones in the spread of bacterial infections. J Infect Dev Ctries 3: 628-632.

Bhoonderowa A, Gookool S and Biranjia-Hurdoyal SD (2014). The importance of mobile phones in the possible transmission of bacterial infections in the community. J Community Health 39(5): 965-967.

Bobat R, Archary M, Lawler M, Mawlana S, Naidoo KL, Maphumulo S and Coovadia Y (2017). The presence and spectrum of bacteria colonizing mobile phones of staff and caregivers in high disease burden paediatric and neonatal wards in an urban teaching hospital in Durban, South 
Africa. Southern African Journal of Infectious Diseases 32: 9-11.

Boyce J.M and Pittet D (2002). Guideline for hand hygiene in health-care settings. MMWR Recomm Rep 51: 1-45.

Chawla K and Mukhopadhayay C, Gurung B, Bhate P and Bairy I (2009). Bacterial 'Cell’ Phones: Do cell phones carry potential pathogens? Online Journal of Health and Allied Sciences 8: 1-5.

CLSI (2012). Performance Standards for Antimicrobial Susceptibility Testing, Vol. 32, Clinical and Laboratory Standards Institute, Wayne, Pa, USA, Twenty-second informational supplement, M 100-S22.

Dave S and Shende K (2015). Toxicology and food technology. Journal of Environmental Science 1(6): 71-73

Debnath T, Bhowmik S, Islam T and Chowdhury HM (2018). Presence of multidrug-resistant bacteria on mobile phones of healthcare workers accelerates the spread of nosocomial infection and regarded as a threat to public health in Bangladesh. Journal of Microscopy and Ultrastructure 6: 165-169.

Fard RH, Moradi M and Hashemipour MA (2017). Evaluation of the cell phone microbial contamination in dental and engineering schools: Effect of antibacterial spray. J Epidemiol Global Health 8(3-4):143-148.

Harmoosh AL, Mutlaq R, Mutlaq N, Alabassi M, Alabassi N, Shamari M, Shamari MA, Khafaji A, Khafaji MA and Hussein. (2017). Surface of Mobile Phone: As a Carrier of Pathogenic Bacteria. Research Journal of Pharmacy and Technology 10(10):1827-1830.

Jonathan W, Holmes MD, Mark D and Williams MD (2010). Methicillin-resistant Staphylococcus aureus screening and eradication in the surgical intensive care unit: Is it worth it? The American Journal of Surgery 200(6) :827-831.

Karkee P, Madhup SK, Humagain P, Thaku N and Timilsina B (2017). Mobile phone: A possible vector of bacterial transmission in hospital setting. Kathmandu Univ Med J 59(3): 217-21.
Kotris I, Drenjančević D, Talapko J and Bukovski S (2016). Identification of microorganisms on mobile phones of intensive care unit health care workers and medical students in the tertiary hospital, Zagreb, Croatia 14(1): 85- 90.

Loyala S, Gutierrez L, Avendarno E, Severino N, Tamariz J (2018). Multidrugs resistant bacteria isolated from cell phones in five intensive care units: Exploratory dispersion analysis. Germs. 8: 85-91.

Madigan M and Martinko J (2006). Brock Biology of Microorganisms (13th ed.). Pearson Education. p. 1096.

Ramesh J, Carter AO, Campbell MH, Gibbons N, Powlett C and Moseley H (2008). Use of mobile phones by medical staff at Queen Elizabeth Hospital, Barbados: evidence for both benefit and harm. J Hosp Infect 70:160-165.

Tagoe DN, Gyande VK and Ansah EO (2011). Bacterial contamination of mobile phones: When your mobile phone could transmit more than just a call. Web Med Central Microbiology 2(10): WMC002294.

Ulger F, Esen S and Dilek A (2009). Are we aware how contaminated our mobile phones with nosocomial pathogens? Ann Clin Microbiol Antimicrob 8:7

Verma D, Barasa A, Dara D, Medehen H, Asrat H, Demissie N, Tegenaw K, Sendeku W and Berhane N (2015). Isolation and characterization of bacteria from mobile phones of students and employees at university of Gondar, Ethiopia. Bulletin of Pharmaceutical Research Institute 5(3):96100.

Viveka VA (2017). Isolation and identification of common bacterial contaminants in mobile phones qwned by veterinary undergraduate students. Journal of Health, Medicine and Nursing 35: 93-105

Worku T, Abateneh D and Kumalo A (2018). Bacterial profile and antimicrobial susceptibility pattern of the isolates from stethoscope, thermometer, and inanimate surface of Mizan-Tepi University Teaching Hospital, Southwest Ethiopia. International Journal of Microbiology Article ID 9824251: 1-7. 